$1-1-1997$

\title{
Lessons from RAPs: Citizen Participation and the Ecology of Community
}

Wendy A. Kellogg

Cleveland State Universithy, w.kellogg@csuohio.edu

Follow this and additional works at: https://engagedscholarship.csuohio.edu/urban_facpub

Part of the Other Environmental Sciences Commons, Social Influence and Political Communication Commons, and the Urban Studies and Planning Commons

How does access to this work benefit you? Let us know!

\section{Publisher's Statement}

(c) 1997 Elsevier

\section{Original Citation}

Kellogg, W. (1997). Lessons from RAPs: Citizen Participation and the Ecology of Community. Journal of Great Lakes Research, 23(2), 227-229. doi:10.1016/S0380-1330(97)70904-3

\section{Repository Citation}

Kellogg, Wendy A., "Lessons from RAPs: Citizen Participation and the Ecology of Community" (1997). All Maxine Goodman Levin School of Urban Affairs Publications. 012368.

https://engagedscholarship.csuohio.edu/urban_facpub/68

This Article is brought to you for free and open access by the Maxine Goodman Levin School of Urban Affairs at EngagedScholarship@CSU. It has been accepted for inclusion in All Maxine Goodman Levin School of Urban Affairs Publications by an authorized administrator of EngagedScholarship@CSU. For more information, please contact library.es@csuohio.edu. 
plans. Identify and pursue only those action plans locally which will significantly and cost effectively address identified impairments in the Areas of Concern (AOC).

\section{SUMMARY}

The Council of Great Lakes Industries supports the RAP process and the restoration of the Great Lakes' water quality. Eliminating regulatory barri- ers, providing incentives for new remedial technologies and strategies, encouraging the use of consensus cost benefit methodologies and prioritizing projects appropriately, will enable RAPs to proceed much more effectively. Quantifiable goals must be biologically based, practical and achievable in the RAP areas of concern. With the successful implementation of RAPs, quality of life will be improved, as will the economic outlook for the present and long term.

\title{
Lessons from RAPs: Citizen Participation and the Ecology of Community
}

\author{
Wendy Kellogg \\ Cleveland State University
}

As we assess the status of Remedial Action Planning we acknowledge both the benefits of participation in RAPs for citizenship and community and the benefits of community participation to the RAPs. How have citizenship and community benefited from Remedial Action Planning? Political scientists describe that for thirty years North Americans have expressed high levels of apathy toward public life and public decision making (Ryan 1991, Phillips 1993). This is a significant change from an idealized but practiced citizenship. What qualities or actions constitute citizenship? A citizen is emotionally attached to a community, committed to its well-being. A citizen actively participates in decisions and actions to ensure community wellbeing. A citizen educates himself or herself to the operation of government, the physical and social conditions in the community, and the possibilities for change.

Our experience of community has changed dur- ing these 30 years as well. Urban scholars trace a change from place-based community (the neighborhood or the village) to communities in metropolitan areas that consist of networks of activities, commonalities of interests, or virtual "spaces" and "highways" over the Internet (Abu-Lughod 1991). The role of citizens has been unique in each RAP, but participation has often been based on and led to a restored sense of community. Using an ecosystem approach, RAPs use the river, bay or entire watershed as the boundary of the study area (Hartig and Law 1994). Participants can find "community" in RAPs whether they seek a place (the river or bay or watershed), a network (the participants and their constituent organizations) or a collective shared end (water quality to support safe fishing, swimming, and use for drinking). By participating, they create a renewed sense of hope, accept responsibility for water quality and enhance their effectiveness. RAP participants see that problems can be addressed as a 
community and sometimes resolved through consensus-building and cooperation. Developing a RAP contributes benefits to the community that reach far beyond restoring water quality.

The role of citizens and stakeholders in partnerships to develop and implement the RAP has nurtured community as well. In most RAPs, citizens and local organizations (government, environmental advocacy groups, community advocacy groups, business and industry groups, etc.) were asked by the lead agency responsible for developing the RAP (or organized themselves) to participate on stakeholder or advisory committees to help identify which remedial actions would best restore and preserve beneficial uses in the Area of Concern (Landre and Knuth 1993). Citizens and stakeholders, representing their neighborhoods, public or private organizations, or advocacy interest groups, have devoted hundreds if not thousands of hours in work sessions with agency staff, at evening and weekend events educating the community about the importance of water quality and the RAP process, and organizing events to raise money to implement remedial actions in their communities (Kellogg 1993). As the IAGLR policy statement so well notes: "The passion and dedication of those involved in the RAP process is rarely articulated. ..." This passion is real, however, and is often the generating spark of citizenship and a renewed sense of community.

How have the RAPs benefited from citizen participation? Local groups are "indispensable" for "attaining a healthy basin ecosystem through place-based action" (IAGLR policy statement). Citizens have contributed scientific or technical knowledge based on their expertise and local experiences. They have sometimes carried out critical research that will be needed "to sustain the successes being measured through the basin" (IAGLR policy statement). Citizens have mobilized information from local universities and planning studies that the lead agency would not have known existed or acquired if not for their participation, as in the Buffalo River RAP.

RAPs are on the "cutting edge" of implementing an ecosystem approach as called for in the GLWQA (WQB statement). Citizens played a significant role in pushing or pulling agencies toward adoption of an ecosystem approach as a conceptual framework and research and action guide in the Hamilton Harbour and Black River RAPs (MacKenzie 1993, Hartig and Law 1994). Citizen participation has made agency priorities more achievable. Citizens have become partners with the agency to mobilize additional resources to carry out agency mandates, as has occurred in the Ohio RAPs and New York RAPs. RAP participants have educated the general citizenry not only about the benefits of clean water, but also about the positive role of a strong agency with adequate resources to improve the community's environmental quality.

Some RAP processes have improved the relationship between agency and community and among often-times adversarial sectors within the community. These changes are most evident in RAPs that have adopted more flexible approaches and management styles, such as in Ontario and Ohio. No RAP process has been easy, however. Many RAP communities and regulatory agencies have a long history of adversarial encounters. Improvements have developed from the ongoing and often tough dialogue between community-based RAP committees and agency staff during development of the RAP. Agency staff have begun to earn the trust of citizens and learned that citizens belong in and improve the planning and management decision making process, as in the Hamilton Harbour, Rouge River and Buffalo River RAPs. Community groups with adversarial pasts have worked together to find consensus, as is illustrated well by the Hamilton Harbour RAP. Citizens and community groups have learned that agency staff are often limited by resources and are more often than not doing their best to meet their responsibilities, as occurred in the Buffalo and Rochester Embayment RAPs.

All of these benefits are valuable to both community and agency, and are key to sustaining the RAPs. These benefits will only likely continue with institutional and financial support from the four parties. Many RAP documents are now completed and designate which remedial actions should be implemented. As every planner and policy analyst has learned, however, the professional and organizational relationships that develop among participants during the planning process are the basis of sustained implementation of planning proscriptions (Forester 1982). These relationships constitute a community of stewards who care about each other's priorities and vision and who are committed to completion of the project as partners. Such communities are particularly important for RAPs, which are not institutionalized as law.

As the policy statements testify, it is difficult to imagine how RAPs could be implemented without direct participation of community-based organiza- 
tions and citizens. They (local governments, regional sewer districts, harbor authorities, industries, zoning boards) will implement many of the actions recommended in the RAP. They (citizens and nonprofit organizations) will sustain interest and support for the RAP over the 10 or more years that will be required to complete remedial actions.

Citizen involvement is likely not enough, however. RAPs have been most successful where true partnerships have developed between citizens, community organizations and the agencies. These partnerships must be maintained to insure that "all stakeholders ... have the opportunity to participate fully" (Council of Great Lakes Industries statement). If the government signatories to the GLWQA continue to withdraw significant financial and agency staff support from the RAPs, citizens and local communities will likely feel betrayed. And they will find it difficult to justify their financial contributions and maintain the high energy levels needed for community participation. Such a situation will dramatically and adversely affect RAP implementation efforts, placing the real gains in water quality restoration made over the last ten years in jeopardy.

\section{REFERENCES}

Abu-Lughod, J. 1991. Changing Cities: Urban Sociology. New York: Harper Collins Publishers.

Forester, J. 1982. Know your organizations: planning and the reproduction of social and political relations. Plan Canada 22(1):3-13.

Hartig, J. H., and Law, N.L. 1994. Progress in Great Lakes Remedial Action Plans: Implementing the Ecosystem Approach in Great lakes Areas of Concern. Environment Canada, Toronto, Ontario, Canada; U.S. Environmental Protection Agency, Chicago, Illinois, U.S.A.

Kellogg, W. 1993. Ecology and Community in the Great Lakes Basin: The Role of Stakeholder and Advisory Committees in Environmental Planning Processes. Dissertation, Cornell University, Ithaca, N.Y.

Landre, B., and Knuth, B. 1993. Success of citizen advisory committees in consensus-based water resources planning in the Great Lakes basin. Society and Natural Resources 6(3):229-257.

MacKenzie, S.H. 1993. Ecosystem management in the Great Lakes: Some observations from three RAP sites. J. Great Lakes Res. 19(1):136-144.

Phillips, W. 1993. The end of politics? A symposium. Partisan Review 60(1):14-41.

Ryan, E. 1991. Growing politics in the backyards of America. Utne Reader 48:86-89.

\title{
The Faltering Search for Community in Great Lakes RAPs
}

\author{
Barry Boyer \\ Law School, State University of New York at Buffalo
}

The Water Quality Board's Position Statement reminds us that "[i]t has been over ten years since the Parties and Jurisdictions committed to the development and implementation of Remedial Action Plans." What have we, the participants and followers of the process, learned during this decade about building a sense of community and shared purpose to preserve one of the earths great ecosystems? Not much, if these statements are any indication. Like the descriptions of the proverbial blind men groping at the elephant, the position statements seem to be describing very different animals; moreover, each group's statement conveys not useful fresh insights derived from experience in the RAP process, but rather the tiresomely familiar refrains of environmental interest group politics in North America.

The Council of Great Lakes Industries, for example, follows a story line that runs back through the 